\title{
A non-stop, single-tube, semi-nested PCR technique for grading the severity of white spot syndrome virus infections in Penaeus monodon
}

\author{
Wansika Kiatpathomchai ${ }^{1}$, Vichai Boonsaeng ${ }^{2, *}{ }^{,}$Anchalee Tassanakajon ${ }^{3}$ \\ Chainarong Wongteerasupaya ${ }^{4}$, Sarawut Jitrapakdee ${ }^{2}$, Sakol Panyim ${ }^{2}$
}

\begin{abstract}
${ }^{1}$ National Center for Genetic Engineering and Biotechnology, Bangkok 10400, Thailand ${ }^{2}$ Department of Biochemistry, Faculty of Science, Mahidol University, Rama VI Road, Bangkok 10400, Thailand ${ }^{3}$ Department of Biochemistry, Faculty of Science, Chulalongkorn University, Phyathai Road, Bangkok 10330, Thailand ${ }^{4}$ Department of Biochemistry, Faculty of Science, Srinakharinwirot University, Sukhumvit 23, Bangkok 10110, Thailand
\end{abstract}

ABSTRACT: A single-tube, non-stop, semi-nested polymerase chain reaction (PCR) technique was developed for simultaneous detection and severity grading of white spot syndrome virus (WSSV) infections in the black tiger shrimp Penaeus monodon. The test uses 1 sense primer and 3 antisense primers that produce up to 3 PCR products $(1100,526$ and 250 base pairs [bp]) depending upon the severity of infection. Specifically, heavy infections $\left(\geq 2 \times 10^{4}\right.$ viral particles $)$ of WSSV produce all 3 fragments, while moderate infections (around $2 \times 10^{3}$ viral particles) produce 2 (526 and $250 \mathrm{bp}$ ) and light infections (20 to 200 viral particles) produce 1 (250 bp). In addition, the technique uses internal control primers that yield a shrimp characteristic fragment for non-infected samples and samples with a low quantity of viral target in order to assure integrity and reproducibility of the PCR assays. The non-stop, single-tube, semi-nested PCR technique is simple and convenient and can detect as little as $5 \mathrm{fg}$ WSSV DNA (20 viral particles) in crude extracts of postlarval samples or extracts of pleopods and haemolymph from larger shrimp.

KEY WORDS: White spot syndrome virus - WSSV · Singletube nested PCR $\cdot$ Penaeus monodon

Resale or republication not permitted without written consent of the publisher

White spot syndrome virus (WSSV) is a viral disease that affects most of the commercially cultivated marine shrimp species, not just in Asia but globally (Wongteerasupaya et al. 1996, Flegel 1997, Lu et al. 1997, Lo et al. 1999, van Hulten et al. 2000). In Thailand, it was first reported as an accidental infection in laboratoryreared shrimp in early 1994 (Wongteerasupaya et al. 1995) although a virus with similar morphology had been reported earlier from farmed specimens of

${ }^{*}$ Corresponding author. E-mail: scvbs@mahidol.ac.th
Penaeus japonicus in Japan (Nakano et al. 1994, Takahashi et al. 1994) and $P$. japonicus, $P$. monodon and $P$. penicillatus in Taiwan (Chen \& Kou 1994).

WSSV is an enveloped, rod-shaped virus, containing double-stranded DNA (Wang et al. 1995, Wongteerasupaya et al. 1995). Contrary to initial speculation (Wongteerasupaya et al. 1995), it is unrelated to baculoviruses (Tsai et al. 2000, van Hulten et al. 2001) and it has been recommended that it be included in a new family tentatively called Whispoviridae or Nimaviridae (van Hulten et al. 2000, 2001). For transmission electron microscopy, negative staining from hemolymph samples revealed that intact virions were $121 \pm 9 \mathrm{~nm}$ in width at the widest point and $276 \pm 26 \mathrm{~nm}$ in length, excluding a multifilament appendage that was often seen attached at the narrow end (Wongteerasupaya et al. 1995). Acutely infected shrimp often show white spots of 0.5 to several $\mathrm{mm}$ in diameter in the cuticle (which are abnormal deposits of calcium) and sometimes also a pink to reddish-brown coloration due to expansion of sub-cuticular chromatophores (Lightner 1996).

WSSV can be detected by histological and molecular techniques, of which PCR is the most sensitive. Currently reported PCR techniques for WSSV detection use either a conventional amplification with a single sense/antisense primer set (Lo et al. 1996a, Kanchanaphum et al. 1998, Withyachumnarnkul 1999) or a nested amplification (Lo et al. 1996b, 1998). Nested PCR provides an increased level of sensitivity compared with conventional single primer-pair PCR. Realtime PCR is more sensitive and has been reported for the quantification of infectious hypodermal and hema- 
topoietic necrosis virus in infected penaeid shrimp (Tang \& Lightner 2001) but not for WSSV.

One of the major drawbacks with 2-step nested PCR is the risk of introducing contamination when a second PCR reaction is initiated using a portion of the mixture from the first reaction vial. This problem can be circumvented by designing a 1-tube, non-stop, seminested PCR where 2 or 3 primer pairs with different melting points are simultaneously added with all reaction components and the test sample in a single tube (Rolfs et al. 1992). The aim of this work was to develop a semi-quantitative PCR detection method for WSSV that can be carried out as a single-tube, non-stop, semi-nested PCR amplification.

Methods and results. WSSV was isolated from experimentally infected juvenile shrimp Penaeus monodon, and the WSSV DNA was extracted from purified virions using phenol-chloroform extraction as described by Wongteerasupaya et al. (1995).

Twenty Penaeus monodon postlarvae or 1 pleopod stored in ethanol were homogenized with a mixture of $200 \mu \mathrm{l}$ of $0.025 \mathrm{~N} \mathrm{NaOH}$ and $0.0125 \%$ sodium dodecyl sulphate in a $1.5 \mathrm{ml}$ microcentrifuge tube, followed by incubation in boiling water for 5 min before immediate incubation on ice. After a brief centrifugation at $10000 \mathrm{rpm}$ in a benchtop microcentrifuge, $5 \mu \mathrm{l}$ of the supernatant was used as the template for PCR amplification.

Ten microliters of hemolymph from Penaeus monodon was mixed with $20 \mu \mathrm{l}$ of $0.005 \mathrm{~N} \mathrm{NaOH}$, incubated at $95^{\circ} \mathrm{C}$ for $5 \mathrm{~min}$ then transferred to ice for 5 min before brief centrifugation. Five microliters of the supernatant was used as the template for PCR amplification.

Using primer analysis software (Oligo 4.0s, National Biosciences, Inc., Plymouth, MN, USA), 1 sense primer (F1) and 3 antisense primers (R1, R2 and R3) were designed from the nucleotide sequence of a $4.2 \mathrm{~kb}$ WSSV clone (Wongteerasupaya et al. 1995). The sequences of these primers are shown in Table 1 . The F1 and R1 primers were used as external primers to generate a primary PCR product of 1100 base pairs

Table 1. Sequences of the primers used. These were designed based on the sequence of a $4.2 \mathrm{~kb}$ cloned fragment derived from purified WSSV and from the sequence of the actin gene of Penaeus monodon

\begin{tabular}{|lllll|}
\hline Primer & \multicolumn{1}{c}{ Sequence } & $\begin{array}{c}\text { Tm } \\
\left({ }^{\circ} \mathrm{C}\right)\end{array}$ & $\begin{array}{c}\text { Target } \\
\text { DNA }\end{array}$ & $\begin{array}{c}\text { Product } \\
\text { size }(\mathrm{bp})\end{array}$ \\
\hline F1 & 5'AGAGCCCGAATAGTGTTTCCTCAGC 3' & 76 & WSSV DNA & - \\
R1 & 5'CAGGCAATATAGCCCGTTTGGG 3' & 68 & WSSV DNA & 1100 \\
R2 & 5'ATTGCCAATGTGACTAAGCGG 3' & 62 & WSSV DNA & 526 \\
R3 & 5'AACACAGCTAACCTTTATGAG 3' & 58 & WSSV DNA & 250 \\
PMN1 & 5'CATGATTATTTTGTATATTATCG 3' & 60 & Shrimp DNA & 143 \\
PMN2 & 5'CAAGTGCTTCTAAGGATACTG 3' & 60 & Shrimp DNA & \\
\hline
\end{tabular}

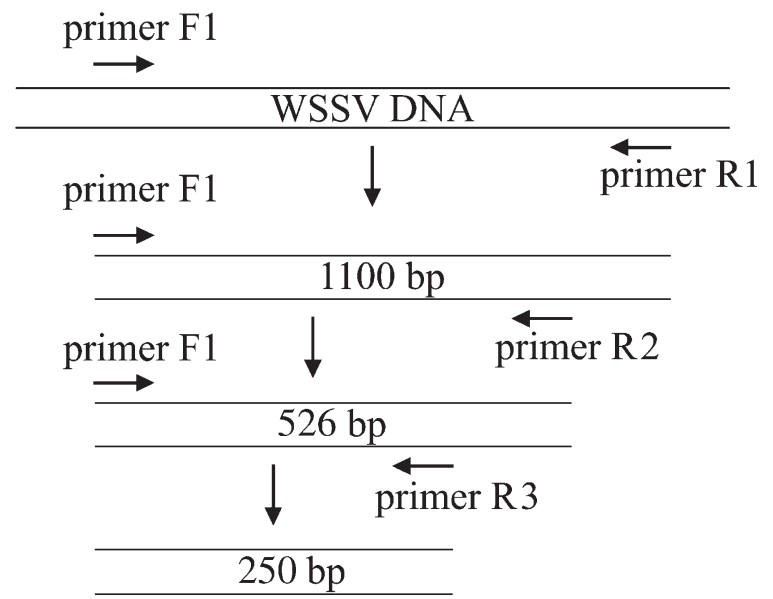

Fig. 1. Diagram showing the products of the non-stop, singletube, semi-nested polymerase chain reaction for detection of WSSV. bp: Base pairs

(bp) while R2 and R3 primers were used as internal primers along with F1 to generate nested PCR products of $526 \mathrm{bp}$ and $250 \mathrm{bp}$, respectively, as shown in Fig. 1.

Primers for the shrimp-specific PCR product comprised primers PMN1 and PMN2 (Table 1) designed from the actin gene of Penaeus monodon (Boonyawan 1998). They produced a fragment of $143 \mathrm{bp}$.

The $50 \mu \mathrm{l}$ PCR reaction contained $50 \mathrm{mM} \mathrm{KCl}$, $10 \mathrm{mM}$ Tris-HCl, $\mathrm{pH} 9.0,1.5 \mathrm{mM} \mathrm{MgCl} 2,0.2 \mathrm{mM}$ each of deoxy (d) ATP, dCTP, dGTP and dTTP, 1 MM F1, $0.2 \mu \mathrm{M} R 1,0.3 \mu \mathrm{M}$ R2, $0.5 \mu \mathrm{M}$ R3, and $0.8 \mu \mathrm{M}$ each of PMN1 and PMN2. The PCR reaction was initiated by heating the mixture to $93^{\circ} \mathrm{C}$ for 5 min followed by addition of $6 \mathrm{U}$ of $\mathrm{Taq}$ polymerase at $75^{\circ} \mathrm{C}$. This was followed by 3 successive cycling protocols of (1) 5 cycles of $93^{\circ} \mathrm{C}$ for $20 \mathrm{~s}, 70^{\circ} \mathrm{C}$ for $20 \mathrm{~s}$ and $72^{\circ} \mathrm{C}$ for $20 \mathrm{~s}$, followed by (2) 20 cycles of $93^{\circ} \mathrm{C}$ for $20 \mathrm{~s}, 55^{\circ} \mathrm{C}$ for $20 \mathrm{~s}$ and $72^{\circ} \mathrm{C}$ for $20 \mathrm{~s}$, followed by (3) 25 cycles of $93^{\circ} \mathrm{C}$ for $20 \mathrm{~s}, 50^{\circ} \mathrm{C}$ for $20 \mathrm{~s}$ and $72^{\circ} \mathrm{C} 20 \mathrm{~s}$. Following PCR, $10 \mu \mathrm{l}$ of the reaction solution was examined following electrophoresis through a $2 \% \mathrm{w} / \mathrm{v}$ agarose gel and ethidium bromide staining.

To determine the sensitivity of the non-stop, semi-nested PCR assay, purified WSSV DNA was serially diluted in 10-fold steps from $50 \mathrm{pg}$ to $0.5 \mathrm{fg}$ and added to normal homogenized postlarval shrimp (i.e., free of WSSV as determined by PCR assay) for use as a template in 1-step nested PCR. By agarose gel electrophoresis, non-stop, semi-nested PCR amplification of these templates produced from 1 to 3 PCR products in a manner dependent upon the quantity of WSSV 


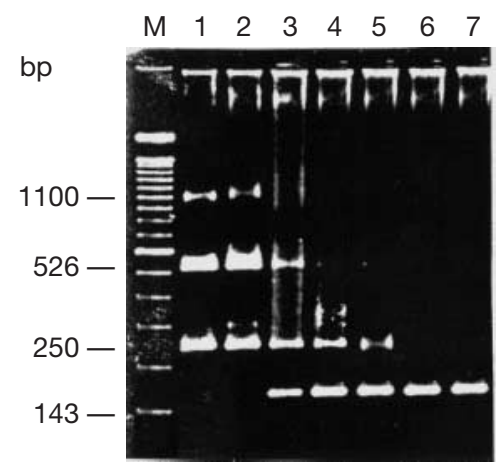

Fig. 2. Sensitivity of the non-stop, single-tube, semi-nested PCR for the detection of WSSV. The PCR products were amplified from purified WSSV DNA serially diluted (1:10) in the range of $50 \mathrm{pg}$ to $0.5 \mathrm{fg}$, added to a homogenate of shrimp postlarvae and extracted as a PCR template (Lanes 1 to 6, respectively). Lane 7 shows the PCR product from a template crude extract of normal postlarvae without added WSSV DNA. The highest dilution still giving a positive reaction was $5 \mathrm{fg}$ of WSSV DNA in crude postlarval homogenate (Lane 5). Lane $\mathrm{M}$ is a $100 \mathrm{bp}$ DNA ladder

added to the homogenates (Fig. 2). Quantities of WSSV DNA at $5 \mathrm{pg}\left(2 \times 10^{4}\right.$ viral particles $)$ and greater gave 3 PCR products of 1100, 526 and 250 bp (Fig. 2, Lanes 1 and 2). A moderate concentration of WSSV DNA, around $500 \mathrm{fg}\left(2 \times 10^{3}\right.$ viral particles), gave 2 products of 526 and $250 \mathrm{bp}$ (Fig. 2, Lane 3) and a low concentration or 5 to $50 \mathrm{fg}$ (20 to 200 viral particles) gave only 1 product of $250 \mathrm{bp}$ (Fig. 2, Lanes 4 and 5). The limit of detection was $5 \mathrm{fg}$ or approximately 20 viral particles
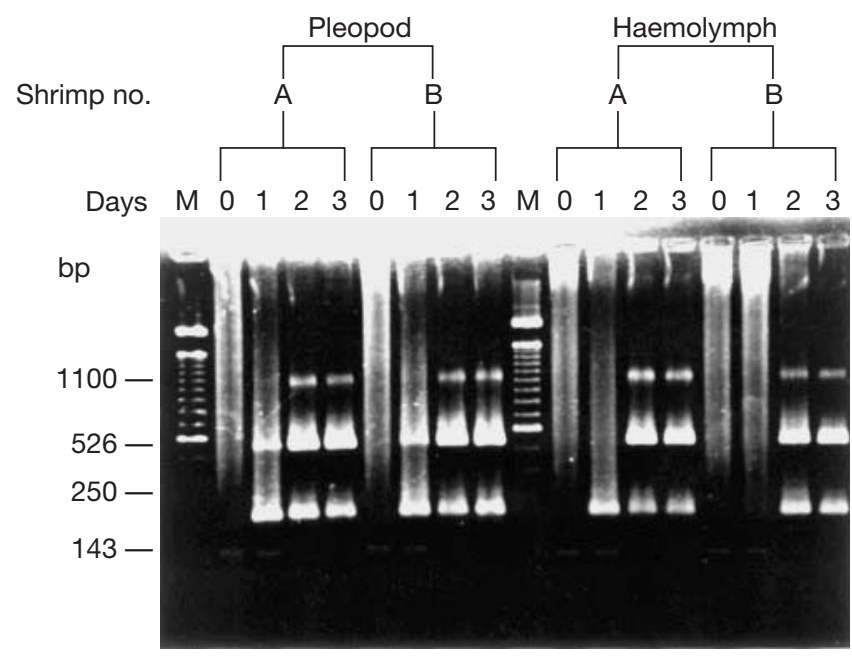

Fig. 3. Ethidium bromide staining of non-stop, single-tube, semi-nested PCR products derived from pleopods and haemolymph of 2 juvenile shrimp (A and B) 1,2 and 3 days after injection with WSSV (Lanes 1, 2 and 3, respectively). Lane 0 is an extract derived before injection of the virus. Lane $\mathrm{M}$ is a $100 \mathrm{bp}$ DNA ladder
(Fig. 2, Lane 5). In addition, a shrimp-specific product at $143 \mathrm{bp}$ was observed for the samples when no or low quantities of WSSV DNA were added (Fig. 2, Lanes 3, $4,5,6$ and 7). When the concentration of the WSSV target was in the range of approximately $500 \mathrm{fg}$ or more, the shrimp-specific, internal control product was not observed.

Detection of WSSV infection in experimentally infected shrimp was tested using tissue and hemolymph derived from 2 juvenile shrimp experimentally infected with WSSV and reared in an aquarium. Hemolymph $(10 \mu \mathrm{l})$ and 1 pleopod were removed daily for testing using the non-stop, semi-nested technique. At $1 \mathrm{~d}$ post injection, 2 PCR products (526 and $250 \mathrm{bp}$ ) were seen from the pleopods of both shrimp (A \& B in Fig. 3) and this increased to 3 fragments $(1100,526$ and $250 \mathrm{bp}$ ) at Days 2 and 3. With hemolymph from both shrimp, only 1 fragment ( $250 \mathrm{bp}$ ) was observed at Day 1 and 3 fragments at Days 2 and 3 . The 143 bp fragment specific for shrimp was seen only in the samples taken at time zero, before WSSV injection.

To test that the non-stop, semi-nested PCR protocol could detect WSSV in field samples of postlarvae, 20 batches were stored in $95 \%$ ethanol and delivered to the laboratory by shrimp farmers. These were typical of the samples usually supplied to commercial test laboratories in Thailand. The postlarvae were removed from alcohol, touched on a paper towel to remove excess alcohol and then processed (i.e., homogenized and extracted as described above) before being tested. A range of results was obtained from 0 to 3 WSSV characteristic fragments. The shrimp-specific marker fragment of $143 \mathrm{bp}$ was seen only with samples that gave either no fragments for WSSV or patterns that indicated low to medium quantities of WSSV.

Discussion. Nested PCR reactions are now used widely in the detection of a number of viruses such as hepatitis C virus (Svoboda-Newman et al. 1996), bovine herpesvirus (Ashbaugh et al. 1997) and fish rhabdoviruses (Miller et al. 1998). They are also used routinely for detection of penaeid shrimp viruses including WSSV (Lo et al. 1996b), monodon baculovirus (Belcher \& Young 1998), gill-associated virus and lymphoid organ virus (Cowley et al. 2000). However, most of these currently described nested PCR methods use conventional steps where a portion of the PCR reaction from the first step is transferred to a second PCR reaction tube for the second (nested) amplification. There is a high contamination risk at this transfer step. By placing all of the reagents for the nested reaction in a single tube and using a 3-phase amplification program, we have attempted to circumvent this potential problem. To our knowledge, the details of a such a semi-quantitative, non-stop, semi-nested PCR detec- 
tion method have not yet been described for any virus of penaeid shrimp.

With respect to sensitivity, we estimate that the lowest detection level of $5 \mathrm{fg}$ of WSSV DNA is equivalent to approximately 20 viral particles based on the estimated length of the total WSSV genome being in the range of $300 \mathrm{~kb}$ (Yang et al. 1997) and assuming only a single copy of the target sequence for the primers. This estimated level of sensitivity is comparable with that of the 2-step nested PCR technique reported by Lo et al. (1998). However, our method is an improvement because it is an uninterrupted, single-tube reaction with reduced risks for contamination. A commercial application of the method of Lo et al. (1998) (Farming IntelliGene Tech. Co., Taipei, Taiwan) uses a single PCR tube but it must be opened after completion of the first PCR step for addition of a reagent premix containing a pair of internal primers for the second PCR step. These tube openings and transfers create additional risks of contamination. One very important advantage of our method is its ability to grade the severity of viral infections to 3 levels. Commercial products that achieve a similar grading are available but information regarding the primers and reagents used are proprietary. Grading of infections has been reported to be important for the management of WSSV in culture systems (Lo et al. 1998, Peng et al. in press), and our technique should provide an open alternative to commercial systems currently offered for the purpose.

Tan et al. (2001) have reported a method for WSSV quantification based on competitive PCR. This may be useful when precise measurements of WSSV quantity are required. However, the method was not suitable for detection of very low viral loads, as is required when shrimp farmers screen potential WSSV carriers and test postlarvae before stocking shrimp ponds. Our method would be more suitable for such routine assays where precise quantification of viral load is not critical.

Various protocols of sample preparation for WSSV detection have been developed using cetyltrimethylammonium bromide followed by chloroform extraction and precipitation of nucleic acids with 2 volumes of absolute ethanol (Lo et al. 1996a) or DNAzol ${ }^{\circledR}$ Reagent (Gibco Life Technologies; Magbanua et al. 2000). These methods are complicated, time consuming, and risk contamination and loss of DNA during the extraction process. We have successfully circumvented the need for this by using a simplified, crude extraction procedure that gives satisfactory results under the conditions of our assay. Using the protocol described in this paper, we have not found evidence of PCR inhibitors since we always obtain either PCR amplicons of expected sizes or the internal control amplicon in test samples. On the other hand, we cannot exclude the possibility that some partial inhibitors might reduce the sensitivity of the assay for WSSV.
Acknowledgements. The authors thank the National Center for Genetic Engineering and Biotechnology and the Thailand Research Fund for grants funding to support this research. They would also like to thank Professors Timothy William Flegel and Boonsirm Withyachumnarnkul for valuable comments and suggestions.

\section{LITERATURE CITED}

Ashbaugh SE, Thompson KE, Belknap EB, Schultheiss PO (1997) Specific detection of shedding and latency of bovine herpesvirus 1 and 5 using a nested polymerase chain reaction. J Vet Diagn Invest 9:387-394

Belcher CR, Young PR (1998) Colourimetric PCR based detection of monodon baculovirus (MBV) in whole Penaeus monodon postlarvae. J Virol Methods 74:21-28

Boonyawan B (1998) Sequence characterization of randomly isolated cDNA from black tiger prawn (Penaeus monodon). MSc thesis. Institute of Molecular Biology and Genetics, Mahidol University, Salaya, Nakhonpathom, Thailand

Chen SN, Kou GH (1994) Viral infection and mass mortality of cultured shrimps in Taiwan. International Symposium on Biotechnology Applications in Aquaculture, 5-10 Dec 1994, Taipei, Taiwan, Asian Fisheries Society, p A2 (Abstract)

Cowley JA, Dimmock CM, Spann KM, Walker PJ (2000) Detection of Australian gill-associated virus (GAV) and lymphoid organ virus (LOV) of Penaeus monodon by RT-nested PCR. Dis Aquat Org 39:159-167

Flegel TW (1997) Major viral diseases of the black tiger prawn (Penaeus monodon) in Thailand. World J Microbiol Biotechnol 13:433-442

Kanchanaphum P, Wongteerasupaya C, Sitidilokratana N, Boonsaeng V, Panyim S, Tassanakajon A, Withyachumnarnkul B, Flegel TW (1998) Experimental transmission of white spot syndrome virus (WSSV) from crabs to shrimp Penaeus monodon. Dis Aquat Org 34:1-7

Lightner DV (ed) (1996) A handbook of shrimp pathology and diagnostic procedures for disease of penaeid shrimp. World Aquaculture Society, Baton Rouge, LA

Lo CF, Leu JH, Ho CH, Chen CH, Peng SE, Chen YT, Chou CM, Yeh PY, Huang CJ, Chou HY, Wang $\mathrm{CH}_{\text {, Kou GH }}$ (1996a) Detection of baculovirus associated with white spot syndrome (WSBV) in penaeid shrimps using polymerase chain reaction. Dis Aquat Org 25:133-141

Lo CF, Ho CH, Peng SE, Chen $\mathrm{CH}$, Hsu HC, Chiu YL, Chang CF, Liu KF, Su MS, Wang CH, Kou GH (1996b) White spot syndrome baculovirus (WSBV) detected in cultured and captured shrimp, crabs and other arthropods. Dis Aquat Org 27:215-225

Lo CF, Chang YS, Cheng CT, Kou GH (1998) PCR monitoring of cultured shrimp for white spot syndrome virus (WSSV) infection in growout ponds. In: Flegel TW (ed) Advances in shrimp biotechnology. National Center for Genetic Engineering and Biotechnology, Bangkok

Lo CF, Hsu HC, Tsai MF, Ho CH, Peng SE, Kou GH, Lightner DV (1999) Specific genomic fragment analysis of different geographical clinical samples of shrimp white spot syndrome virus. Dis Aquat Org 35:175-185

Lu Y, Tapay LM, Loh PC, Brock JA, Gose R (1997) The pathogenicity of a baculo-like virus isolate from diseased penaeid shrimp obtained from China for cultured penaeid species in Hawaii. Aquacult Int 5:277-282

Magbanua FO, Natividad KT, Migo VP, Alfafara CG, da la Pena FO, Miranda RO, Albaladejo JD, Nadala ECB, Loh 
PC, Tapay LM (2000) White spot syndrome virus (WSSV) in cultured Penaeus monodon in the Philippines. Dis Aquat Org 42:77-82

Miller TA, Rapp J, Wasthuber U, Hoffmann RW, Enzmann PJ (1998) Rapid and sensitive reverse transcriptase-polymerase chain reaction based detection and differential diagnosis of fish pathogenic rhabdoviruses in organ samples and culture cells. Dis Aquat Org 34:13-20

Nakano H, Koube H, Umezawa S, Momoyama K, Hiraoka M, Inouye K, Oseko N (1994) Mass mortalities of cultured kuruma shrimp, Penaeus japonicus in Japan in 1993: epizootiological survey and infection trials. Gyobo Kenkyu (Fish Pathol) 29:135-139

Peng SE, Lo CF, Lin SC, Chen LL, Chang YS, Liu KF, Su MS, Kou GH (2001) Performance of WSSV-infected and WSSV-negative Penaeus monodon postlarvae in culture ponds. Dis Aquat Org 46:165-172

Rolfs A, Scholler I, Finckh U, Rolfs IW (1992) General applications of PCR. In: Rolfs A (ed) PCR: clinical diagnostics and research. Springer-Verlag, Berlin, p 34-50

Svoboda-Newman SM, Greenson JK, Singleton TP, Sun R, Frank TS (1996) Detection of hepatitis C in paraffin fixed liver using RT-PCR. Modern Pathol 9:137A

Takahashi Y, Itami T, Kondo M, Maeda M, Fuji R, Tomonaka S, Supamattaya K, Boonyaratpalin S (1994) Electron microscopic evidence of bacilliform virus infection in kuruma shrimp (Penaeus japonicus). Fish Pathol 29:121-125

Tan LT, Soon S, Lee KL, Shariff M, Hassan MD, Omar AR (2001) Quantitative analysis of an experimental white spot syndrome virus (WSSV) infection in Penaeus monodon Fabricus using competitive polymerase chain reaction. J Fish Dis 24:315-323

Tang KFJ, Lightner DV (2001) Detection and quantification of infectious hypodermal and hematopoietic necrosis virus in penaeid shrimp by real-time PCR. Dis Aquat Org 44: $79-85$

Tsai MF, Yu HT, Tzeng HF, Leu JH, Chou CM, Hung CJ, Wang CH, Lin JY, Vlak JM, Kou GH, Lo CF (2000) Identi-

Editorial responsibility: Carey Cunningham,

Aberdeen, Scotland, UK fication and characterization of a shrimp white spot syndrome virus (WSSV) gene that encodes a novel chimeric polypeptide of cellular-type thymidine kinase and thymidylate kinase. Virology 277:100-110

van Hulten MCW, Tsai MF, Schipper CA, Lo CF, Kou GH, Vlak JM (2000) Analysis of a genomic segment of white spot syndrome virus of shrimp containing ribonucleotide reductase genes and repeat regions. J Gen Virol 81: 307-316

van Hulten MCW, Witteveldt J, Peters S, Kloosterboer N, Tarchini R, Fiers M, Sandbrink H, Lankhorst RK, Vlak JM (2001) The white spot syndrome virus DNA genome sequence. Virology 286:7-22

Wang CH, Lo CF, Lou JH, Chou CM, Yeh PY, Chou HY, Tung MC, Chang CF, Su MS, Kou GH (1995) Purification and genomic analysis of baculovirus associated with white spot syndrome (WSBV) of Penaeus monodon. Dis Aquat Org 23:239-242

Withyachumnarnkul B (1999) Results from black tiger shrimp Penaeus monodon culture ponds stocked with postlarvae PCR-positive or -negative for white spot syndrome virus (WSSV). Dis Aquat Org 39:21-27

Wongteerasupaya C, Vicker JE, Sriurairatana S, Nash GL, Akarajarmorn A, Boonsaeng V, Panyim S, Tassanakajon A, Withyachumnarnkul B, Flegel TW (1995) A nonoccluded, systemic baculovirus that occurs in cells of ectodermal and mesodermal origin and causes high mortality in the black tiger prawn Penaeus monodon. Dis Aquat Org 21:69-77

Wongteerasupaya C, Wongwisansri S, Boonsaeng V, Panyim S, Pratanpipat P, Nash GL, Withyachumnarnkul B, Flegel TW (1996) DNA fragment of Penaeus monodon baculovirus PmNOBII gives positive in situ hybridization with white-spot viral infections in six penaeid shrimp species. Aquaculture 143:23-32

Yang F, Wang W, Chen RZ, Xu X (1997) A simple and efficient method for purification of prawn baculovirus DNA. J Virol Methods 67:1-4

Submitted: April 30, 2001; Accepted: September 3, 2001 Proofs received from author(s): November 19, 2001 